\title{
The Leap to the City: Resistance and transition in a Chinese village facing urbanisation
}

\section{Boris Svartzman}

Translator. Michael Black

\section{(2) OpenEdition}

\section{Journals}

\section{Electronic version}

URL: http://journals.openedition.org/chinaperspectives/6104

DOI: 10.4000/chinaperspectives.6104

ISSN: 1996-4617

\section{Publisher}

Centre d'étude français sur la Chine contemporaine

\section{Printed version}

Date of publication: 15 March 2013

Number of pages: 41-52

ISSN: 2070-3449

\section{Electronic reference}

Boris Svartzman, «The Leap to the City: Resistance and transition in a Chinese village facing urbanisation », China Perspectives [Online], 2013/1 | 2013, Online since 01 March 2016, connection on 28 October 2019. URL : http://journals.openedition.org/chinaperspectives/6104 ; DOI : 10.4000/

chinaperspectives.6104 


\title{
The Leap to the City: Resistance and transition in a Chinese village
} facing urbanisation

\author{
BORIS SVARTZMAN
}

\begin{abstract}
This article is based on a field survey conducted in a village whose lands were expropriated, its homes destroyed, and its inhabitants relocated to two blocks of flats built about a hundred metres from the village, and in which new neighbourhood administrations were set up. Supervision of the evictions by local authorities seems crucial in the process of adapting former villagers to their status as urban dwellers. However, the interactions between cadres and people in their new urban setting cannot be understood without taking into account the resistance that preceded the eviction, a resistance that we will seek to reconstruct.
\end{abstract}

KEYWORDS: conflict, expropriation, population displacement, migration, urbanisation, transition, property.

$P$ rior to 1980, Chinese population movements were severely limited by residence registers, both rural (rural hukou) and urban (non-rural hukou). (1) However, while about 80 percent of the population lived in the countryside in the early 1980s, China's urban population officially passed the 50 percent mark in 2011, evidence of a historically unprecedented rural exodus. (2)

China initially experienced increasing migration with the industrial boom in the coastal areas since the 1980s, and the growing need for manpower. ${ }^{(3)}$ Rural inhabitants were gradually able to leave their villages, but without the hukou system being abolished. (4) Migrants working in the city without legal residence permits were unable to access the social services available to the urban population. ${ }^{(5)}$ They therefore made up a continuously increasing "floating" population, currently estimated at over 220 million people. (6)

A second high point of urbanisation in China was reached in the early 1990s with the expansion of the cities. (7) Between 1996 and 2006, the area of land occupied by Chinese cities grew by 50 percent, ${ }^{(8)}$ and over 80 percent of urban expansion took place in the developed regions of the east through the requisition of arable land. (9) In statistical terms, former rural dwellers who in this way suddenly acquire the status of urban residents can be seen as part of the rural population migrating to cities. However, in reality, it is the cities that are "eating up" their land. (10)

The government has gradually transformed the "rural hukou" among this population into "non-rural hukou," marking their definitive emergence from the status of peasants. However, these former rural dwellers are not considered "landless." (11) Instead, this new urban population stands apart from peasant migrants because it has experienced the process of urbanisation in a radically different way: it has become urban without migrating (whereas a large number of migrants struggle to acquire urban status while keeping land in the village where their hukou is registered). This change of status without migration might accounts for 40 percent of urbanisation in China. ${ }^{(12)}$

\section{The political implications of requisitions}

The differentiation between urban and rural populations established by the Chinese Communist Party helped to divide ownership of the land into two broad categories: urban land, which the state holds, and rural lands,

1. Hukou, the family register that classifies individuals according to their place of birth into two broad categories of population, agricultural and non-agricultural, has regulated internal mobility for decades, forbidding farmers access to the city while urban dwellers benefited from the welfare state set up by the Communist regime. Kam Wing Chan, "The Chinese Hukou System at 50," Eurasian Geography and Economics, Vol. 50, No. 2, 2009, pp. 197-221.

2. Kam Wing Chan, "Crossing the 50 Percent Population Rubicon: Can China Urbanize to Prosperity?", Eurasian Geography and Economics, Vol. 53, No. 1, 2012, pp. 63-86.

3. Claude Aubert et al., "Agricultural Underemployment and Rural Migration in China: Facts and Figures," China Perspectives, No. 41, 2002, pp. 47-58.

4. Kam Wing Chan, "Fundamentals of China's Urbanisation and Policy," The China Review, Vol. 10, No. 1, 2010, pp. 63-94.

5. Dorothy J. Solinger, "The creation of a new underclass in China and its implications," Environment and Urbanisation, Vol. 18, No. 1, 2006, pp. 177-193.

6. Chloé Froissart, "Les migrations intérieures en Chine" (Internal migrations in China), in Christophe Jaffrelo (ed.), L'Enjeu mondial (Le phénomène migratoire) (The global challenge [migrations]), Presses de Sciences Po, Paris, 2009.

7. Kam Wing Chan et al., "Urbanisation in China in the 1990s: New Definition, Different Series, and Revised Trends," The China Review, Vol. 3, No. 2, 2003, pp. 49-71.

8. Xu Ying et al., "State-led land requisition and transformation of rural villages in transitional China," Habitat International, No. 35, 2011, p. 57.

9. Shengjing He et al.," Property Rights Redistribution, Entitlement Failure and the Impoverishment of Landless Farmers in China," Urban Studies, Vol. 46, No. 9, pp. 1925-1949.

10. George C. S. Lin, "The State, Land System, and Land Development Processes in Contemporary China," Annals of the Association of American Geographers, Vol. 95, No. 2, 2005, pp. 411-436.

11. A social category that does not exist in China, unlike in Brazil: Susana Bleil, "L'occupation des terres et la lutte pour la reconnaissance: l'expérience des sans-terre au Brésil" (The occupation of lands and the fight for recognition: The experience of the "landless" in Brazil), Mouvements, No. 65, 2011, pp. 107-119. In China, according to official statistics, the average per capita agricultural land has remained relatively stable between 2000 and 2008, about 0.7 hectare per capita. (China Statistical Year Book, 2000, 2005, 2009).

12. Rural migration to small and medium-sized cities, where obtaining a hukou is easier than in the 40 largest cities in China, also accounts for 40 percent of urbanisation. See Kam Wing Chan, "Crossing the 50 Percent Population Rubicon: Can China Urbanize to Prosperity?", op. cit. 


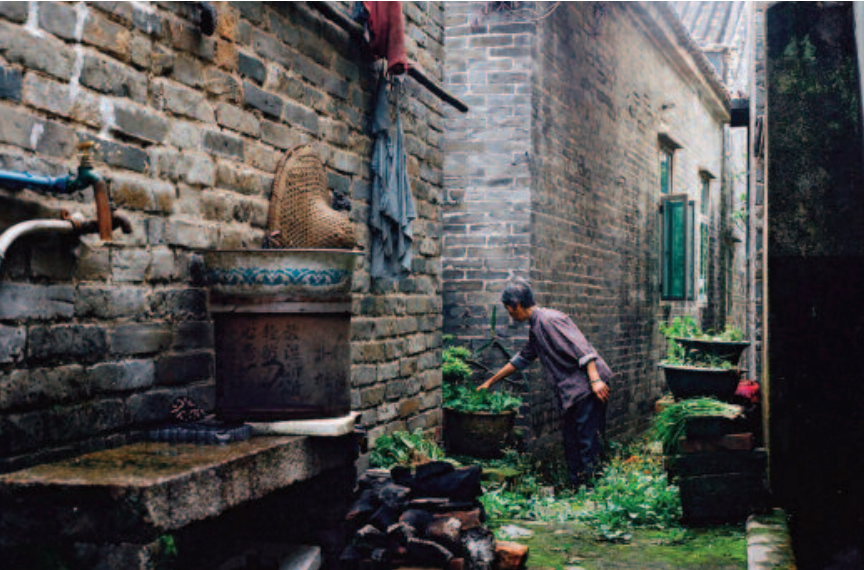

A woman in one of the village streets

(c) Boris Svartzman

which are owned "collectively" by village communes. ${ }^{(13)}$ Since the beginning of the reforms initiated by Deng Xiaoping and the dismantling of the communes, the state has progressively strengthened the protection of private property, which was written into the Chinese Constitution in 2007.

However, private ownership of property is recognised only in urban areas, contributing to a system of private property in the city that is at odds with a system of collective ownership in the country. ${ }^{(14)}$ In the city, the state owns the land, but private ownership of property is recognised. In rural areas, land has been registered since the 1950s under collective ownership. Farmers have only the usufruct of land allocated among all the inhabitants of the village for the construction of housing or for agriculture. Thus, farmers cannot freely sell the land they cultivate or on which their homes are built because they are not the owners, while the state may requisition such land without there being "expropriation" in legal terms. With the transition from a planned economy to a market economy, requisition of rural land has meant for rural communities a form of nationalisation, rather than the privatisation of their principal means of production, the land. However, farmers are all the more inclined to resist local authorities for the preservation of land they consider as belonging to them collectively. ${ }^{(15)}$

Chinese urban expansion has come about by the expansion of cities into rural peri-urban areas, involving massive rural land requisition. ${ }^{(16)}$ Since the strengthening of economic reforms in 1992, about 3 million farmers per year have seen their collective land requisitioned, or about 60 million people since the resumption of reforms. ${ }^{(17)}$ In order to transfer agricultural land to non-agricultural use, local authorities must seek the approval of the Ministry of Land Management to convert agricultural land to urban land. (18)

However, between 1995 and 2005, about 600,000 cases of violation of peasants' rights were recorded by the People's Supreme Court. ${ }^{(19)}$ Over the same period, 65 percent of "mass protests" are said to have been linked to expropriation problems. ${ }^{(20)}$ From this point of view, resistance to expropriation, regularly reported in the press and in documentary films, ${ }^{(21)}$ can be seen as a manifestation of social instability that challenges political legitimacy, at least that of local authorities who profit from the transfers of land. (22)

A large number of analyses of urbanisation deal with the problems of requisition, with the possibilities of complaint in the rural world, (23) and with the enrichment of cadres. (24) But there are very few studies that take into account the power relations underlying the expropriations as a stage in the process of transformation of rural communities in China into a new urban class. On this question, Xu Ying et al. write that there is a "lack of compre- hensive understanding about how the rural population, despite now being housed in and surrounded by an urban setting, has gradually adapted to or resisted the forces of urbanisation instigated by the state." (25) This article will therefore attempt to show the connections between the disappearance of the peasantry, the complaints procedures in China, and the formation of a new urban population through a survey of the requisition of agricultural land and the destruction of a village, followed by the relocation of all its residents to two apartment blocks a few hundred meters from the original site of the village. We will then seek to understand how the repression of the people determines their adaptation to the urban life imposed on them.

\section{Presentation of the village and of the survey}

\section{History of the village}

Before 2008, the village of Xiaodao ${ }^{(26)}$ (Xiaodao cun) was located on the island of Xiaodao (Xiaodao dao), in the district of Haizhu (Haizhu qu) in a peri-urban area of Guangzhou, in the Pearl River Delta. There was no bridge to the opposite shores, and the village was known in the area as "the poor

13. Peter Ho, "Who Owns China's Land? Policies, Property Rights, and Deliberate Institutional Ambiguity," China Quarterly, No. 394, 2001, pp. 397-401.

14. See Valerie Jaffee Washburn, "Regular takings or regulatory takings?: Land expropriation in rural China," Pacific Rim Law \& Policy Journal, Vol. 20, No. 1, 2011, pp. 71-124.

15. The transition of countries that experienced the end of communism is generally studied through the privatisation of state enterprises in urban areas, and more rarely through the prism of rural transformations. See J. Kornai, "The Great Transformation of Central Eastern Europe: Success and Disappointment," Economics of Transition, Vol. 14, No. 2, 2006; B. Chavance et al., "Trajectoires post-socialistes et capitalismes occidentaux," in J.-P. Faugère et al. (eds.), Convergence et diversité à l'heure de la mondialisation, Economica, 1997; Melinda Herrold-Menzies, "The Post-Collective Village: A Tale of Two Transitions," World Development, Vol. 37, No. 1, 2009, pp. 232-241.

16. Rong Tan et al., "Rural to urban land conversion in China: How large is the over-conversion and what are its welfare implications?", China Economic Review, Vol. 22, No. 4, 2011, pp. 474-484.

17. He Bochuan, "La crise agraire en Chine. Données et reflexions" (The agriculture crisis in china: Data and reflections), Études rurales, No. 179, 2007, p. 124.

18. Chengri Ding, "Policy and praxis of land acquisition in China," Land Use Policy, Vol. 24, 2007, pp. 1-13.

19. He Bochuan, op. cit., pp. 120.

20. Ed Zhang, South China Morning Post, as noted by BBC Monitoring, 19 June 2011.

21. One of the most recent cases reported in the international media is the village of Wukan, in Guangdong Province. See in particular the special issue of iSunAffairs, HK, 15 December 2011, pp. 20-32 (in Chinese). Researcher Ai Xiaoming has made a documentary, Wukan sanri (Three Days in Wukan), which shows the organisation of village resistance and the massive presence of foreign journalists in the barricaded village.

22. On the expulsion process, see Susan Whiting, "Values in Land: Fiscal Pressures, Land Disputes and Justice Claims in Rural and Peri-urban China," Urban Studies, Vol. 48, No. 3, 2011, pp. 569-587; Steve Hess, "Nail Houses, Land Rights, and Frames of Injustice on China's Protest Landscape," Studies on Asia, Series IV, No. 1, 2010; John Meligrana et al., "Resolving Land Use Disputes in China: An Analysis of a Method of Dealing with Citizen Complaints," Environment and Urbanisation Asia, Vol. 2, No. 2, 2011, pp. 251-264; Andrew C. Mertha, "From 'Rustless Screws' to 'Nail Houses': The Evolution of Property Rights in China," Orbis, 2009, pp. 233-249; Valérie Laurans, "Shanghai: Modern Conveniences as an Argument for Displacing Residents," China Perspectives, No. 58, 2005, pp. 10-21; Human Rights Watch, "Demolished: Forced Evictions and the Tenant's Rights Movement in China," Vol. 16, No. 4, 2004, pp. 22-31; Liu Qing, "The Legal Time Bomb of Urban Development," China Rights Forum, No. 2, 2003, pp. 68-72.

23. Isabelle Thireau et al. (eds.), Disputes au village chinois (Arguments in a Chinese village), MSH, Paris, 2001; Kevin J. O'Brien et al. (eds.), Rightful Resistance in Rural China, Cambridge, 2006; Isabelle Thireau et al., Les ruses de la démocratie. Protester en Chine (The tricks of democracy: To protest in China), Seuil, 2010.

24. George C. S. Lin et al., "Urbanization of capital or capitalization on urban land? Land development and local public finance in urbanizing China," Urban Geography, Vol. 32, No. 1, 2011, pp. 50-79; Erik Lichtenberg, "Local officials as land developers: Urban spatial expansion in China," Journal of Urban Economics, No. 66, 2009, pp. 57-64; Lixing Li, "The incentive role of creating "cities" in China," China Economic Review, Vol. 22, No. 1, 2011, pp. 172-181; Jianfa Shen et al., "Dual-track urbanisation in a transitional economy: The case of Pearl River Delta in South China," Habitat International, Vol. 30, 2006, pp. 690-705.

25. Cf. Xu Ying et al., op. cit., pp. 58.

26. The names of people and places have been changed. 


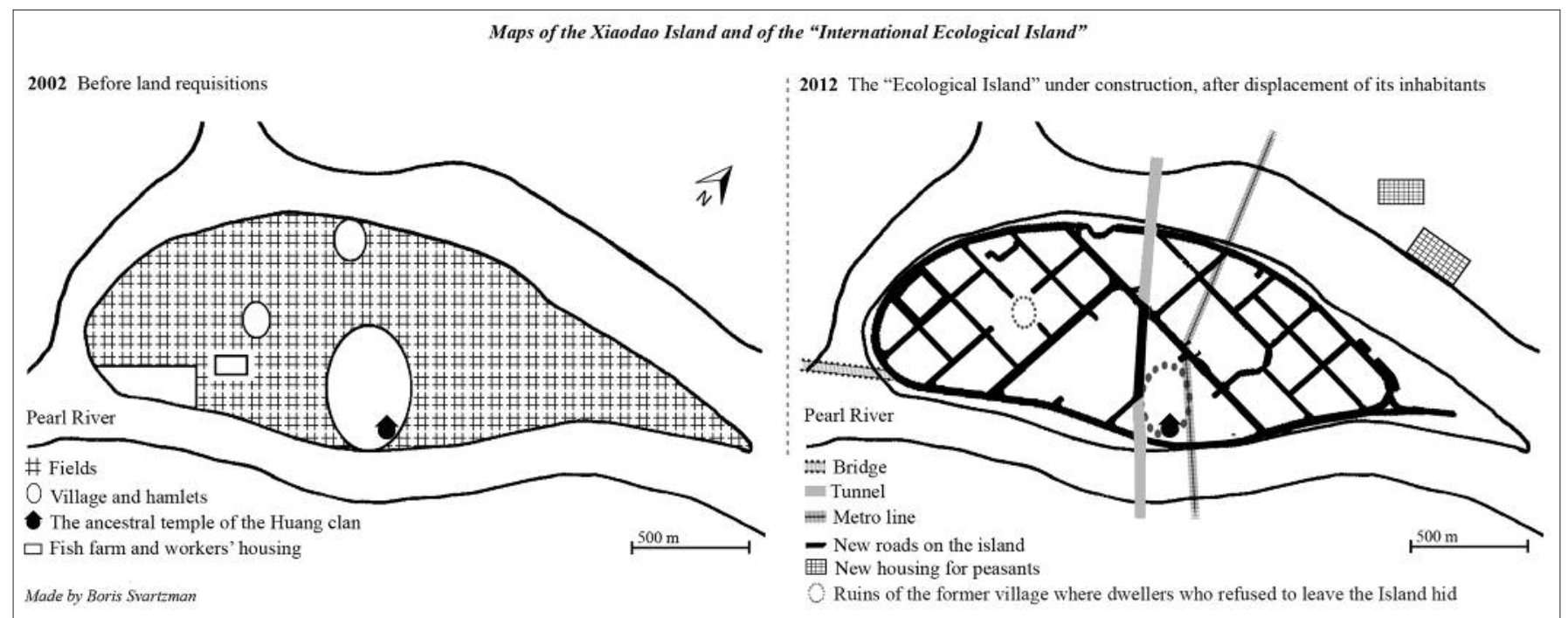

Aerial view of the Xiaodao Island @ Boris Svartzman

village" (qiongcun), because of its isolation. Consisting of three hamlets, it had 2,000 inhabitants of the same clan, the Huangs, represented by a single ancestral temple on the island. (27)

The village also included a hundred overseas Chinese (Huaqiao), living mainly in Hong Kong, who, thanks to the opening up measures since the 1980 , had been able to recover property expropriated in the early years of the communist regime, and in some cases invest in the construction of new houses. ${ }^{(28)}$ In addition, a state enterprise was built in the early 1980s, with four plants dedicated to fishing and related activities (maintenance of boats, fish processing, etc.) on a portion of the land on the island away from the village. Two blocks of flats were built on the island to accommodate more than 350 families of workers who were employed there. Because of their jobs, they held non-rural hukou and benefited from state welfare (social contributions, retirement pensions, unemployment benefits, a medical centre and primary school reserved for factory workers). These workers thus formed a separate community. ${ }^{(29)}$

The peasants who constituted about 75 percent of the inhabitants of the island were therefore at the bottom of the social scale, and did not receive social assistance because of their rural status. ${ }^{(30)}$ The conditions of village life improved significantly in the 1980s with the establishment of the Family Responsibility System. ${ }^{(31)}$ Many farmers then abandoned vegetable crops in favour of planting fruit trees. Surplus manpower was able to go to work in the city, returning only to harvest the fruit crops, which were sold at a good price due to the proximity of urban markets. The isolation of the island became an asset for agriculture in an area in full expansion, ${ }^{(32)}$ and the villagers began for the first time in decades to invest in the construction of new houses. ${ }^{(33)}$

At the same time, construction projects increased in the district: some villages were deprived of their agricultural land, while others were completely destroyed. A dozen villages opposite the island were expelled in the early 2000s for the construction of the University City of Guangdong, which now has more than 100,000 students, several stadiums, a hospital, and a few houses of a traditional village transformed into a tourist park. ${ }^{(34)}$ The largest exhibition centre in China, which hosts many international fairs throughout the year, was also built less than a mile from the village. ${ }^{(35)}$

Finally, the village was overtaken in the 2000s by the surrounding urbanisation. The extension of the metro line from Guangdong arrived on the is- land, and a tunnel connecting the island to the opposite banks was begun. In 2004, the district authorities announced that the island of Xiaodao was to be requisitioned for an "International Ecological Island" construction project. At the end of 2005, the fish factory closed down and the fields were razed, and at the end of 2008, the farmers were evicted and moved into two blocks of flats built just opposite the island. A hundred villagers refused to sign the displacement agreement and took refuge in the temple of their ancestors, a National Heritage building, as well as in the homes of the Huaqiao, which had not yet been destroyed because these people living abroad were supposed to be entitled to extraordinary compensation, which had not yet been decided in October 2012.

In May 2012, when I last visited, two parks with artificial hills to admire the view and a bike path along the water had been constructed, and tourists could rent bicycles at the subway exit, stop at a Western-style bar, and visit the model of the construction project of the island, on which it is clearly intended to build villas and luxury homes.

27. According to a book retracing the local history of the village, which was published in 2004.

28. On the return of the Huaqiao, cf. Ellen Oxfeld, "Imaginary homecomings: Chinese villagers, their overseas relations, and social capital," Journal of Socio-Economics, Vol. 30, 2001, pp. 181-186; Glen Peterson, "Overseas Chinese and Merchant Philanthropy in China: From Culturalism to Nationalism," Journal of Chinese Overseas, Vol. 1, No. 1, 2005, pp. 87-109.

29. Marie-Ange Maurice, "50 ans de protection sociale en Chine: acquis et réformes (1949-1997)," (50 years of social protection in China: Gains and reforms), Revue française des affaires sociales, 2001, No. 2, pp. 145-169.

30. Fang Cai, "Hukou System Reform and Unification of Rural-urban Social Welfare," China \& World Economy, Vol. 19, No. 3, 2011, pp. 33-48.

31. The Family Responsibility System restored the freedom of farmers to cultivate their own plots of land, thus dismantling rural cooperatives. Cf. Claude Aubert et al., "'Peasant burden': Taxes and levies imposed on Chinese farmers," Agricultural policies in China after WTO accession, OECD, Paris, 2002, pp. 160-179

32. Bochuan He, "L'essor des marchés dans les villages de la rivière des Perles," (The expansion of village markets in the Pearl River Delta), Études rurales, No. 161-162, 2002, pp. 89-107.

33. On a similar topic, see Alan De Brauw et al., "Migration and household investment in rural China," China Economic Review, Vol. 19, No. 2, 2008, pp. 320-335; Bingqin Li, "Migrants as a source of revenue in small towns in China," Environment and Urbanisation, Vol. 22, 2010, pp. 51-66.

34. On the displacement of the Island's inhabitants, see the documentary films: University Savage, Ima Savage (a pseudonym), 83 min., self production, 2005; Dragon Boat, Cao Dan, 85 min., CNEX, Taiwan, 2011.

35. See Églantine Jastrabsky, "Le poids de Canton" (The weight of Guangzhou), Outre-Terre, No. 15, 2006, pp. 161-177. 


\begin{tabular}{|l|c|c|c|c|} 
& $\begin{array}{c}\text { Village inhabitants } \\
\text { (holding } \\
\text { a rural hukou: } \\
2,300 \text { people) }\end{array}$ & $\begin{array}{c}\text { Workers } \\
\text { (holding a non-rural } \\
\text { hukou: 62 plaintiffs out } \\
\text { of 351 worker families) }\end{array}$ & $\begin{array}{c}\text { Landowners who came } \\
\text { back to the village } \\
\text { (holding a non-rural } \\
\text { hukou) }\end{array}$ & $\begin{array}{c}\text { Huaqiao } \\
\text { (out of 60 people, } \\
\text { only one couple who } \\
\text { lost its two houses) }\end{array}$ \\
\hline $\begin{array}{l}\text { Inhabitants' complaints } \\
\text { sent to the government }\end{array}$ & 5 & 4 & 2 & 4 \\
\hline $\begin{array}{l}\text { Answers from } \\
\text { the government }\end{array}$ & 4 & 3 & 2 & 2 \\
\hline $\begin{array}{l}\text { Letters from the authori- } \\
\text { ties to the inhabitants }\end{array}$ & 5 & 9 & 3 & 2 \\
\hline Legal cases & 2 & - & 6 & 4 \\
\hline
\end{tabular}

\section{Conditions of the survey}

I made two trips to the island of Xiaodao, in 2007 and 2008, before the eviction of the village. I met a couple of workers who, having befriended several farmers, became my informants and allowed me access to the homes of villagers in the blocks of flats. I returned for stays in 2009, 2011, and 2012, in order to investigate the adaptation of the villagers to their blocks of flats in the suburbs of Guangzhou.

Thirty interviews were conducted with villagers and former fish factory workers. Over the years, these people gave me a number of documents relating to requisitions, including 57 complaints and letters of response from the authorities (see Table 1), hundreds of documents in legal files, 14 internal documents concerning the carrying out of requisitions, several maps of the island, photographs and videos taken with their mobile phones during the requisitions of the village, and 17 clippings of newspaper articles.

However, my presence strongly disturbed the authorities, and only people dissatisfied with the expulsion dared to speak to me. In 2009, shortly after the relocation, I was simply denied access to the blocks of flats. I returned in 2011 and 2012. Residents invited me to eat at their homes, but a few days later they were questioned. The police probably feared that I was a journalist, because they tried to find out what questions I had asked and they asked my interlocutors if they had "talked to the foreigner about the problems of the village." I had introduced myself to people who received me as a teacher interested in Chinese traditional culture, an explanation they repeated to the authorities, who were apparently reassured enough to not come and intimidate me directly. ${ }^{(36)}$

My interlocutors nevertheless stopped inviting me to their homes, some deciding that it was better not to talk to me at all, even outside the buildings. I thought then that my investigation of the adaptation of people to their new housing block was going to be unsuccessful. In this context it was even more difficult for me to get the perspective of people satisfied with the relocation or that of the village cadres.

But I continued to meet with workers who had been rehoused in the suburbs and with the remaining inhabitants who were holding out on the island, where, strangely enough, I was able to circulate much more freely than in the new apartment blocks. Finally one of the locals gave me the contact details of a couple of Huaqiao residing in Hong Kong, who had initiated a lawsuit against the authorities after the destruction of their two houses that were on the route of the tunnel. My investigation thus shifted to the resistance that preceded this transition.

The documents that all these people gave me mainly contain information about the opposition of the inhabitants to the process of expulsion and to the resettlement of the inhabitants of the island, which allowed me to reconstruct a large number of events that took place between the late 1990s and 2012

I also downloaded 134 reports of Subdistrict Offices (jiedao banshichu), in the Haizhu district, and the city of Guangzhou from the websites of these agencies, and consulted local administrative records (difang zhi), ${ }^{\left({ }^{37}\right)}$ enabling me to reconstruct the geographical and administrative context of the displacement of the village. Due to the number of actions that took place simultaneously among the various population groups living on the island, and the lack of data on entry into the new blocks of flats, I have used as a main theme the resistance of the peasants that preceded the urban transition they experienced, and I will only occasionally refer to the other inhabitants of the island.

\section{Case study: An inevitable expulsion}

\section{The institutional preliminaries to the expulsion of the villagers}

Until 2002, the island of Xiaodao was under the direction of two administrations: the urban district of Haizhu, which managed the urban population, and the township of Xinjiao, which managed the rural population. The township of Xinjiao thus supervised fifty "natural" villages, but with the urbanisation of the territory, the border between the rural and urban areas faded, causing tension between the two administrations. To address these problems, the municipal authorities decided in March 2002 to abolish the borough of Xinjiao. The 64,879 inhabitants of the villages concerned then lost their rural hukou, which were changed into non-rural hukou, and

36. Many cases of physical threats and even violent crackdowns on outside observers of expropriations have appeared in the press. See for example: AFP, "Chine: deux journalistes étrangers malmenés dans un village" (China: Two foreign journalists mangled in a village), 7 October 2005.

37. These can be consulted at the University Science Centre of the Chinese University in Hong Kong. 
146 Residents' Committees were created under the supervision of the Subdistrict Offices of the district of Haizhu, including the village of Xiaodao.

Along with this change of hukou, an "Ecological Park" project was filed in 2000 by the Haizhu District with the city of Guangzhou, without the knowledge of the villagers. The residents say they suspected nothing at the time. In fact, the village's tree plantations were part of the district's "10,000 Fruit Tree Park," which gave the villagers the feeling of being safe from requisitions. In 2012, a certain Huang had this to say on the subject:

How could we understand the implications of these changes? [...] We had kept our plots of farmland. In addition, at the time young people like me were working outside the village. With the change of hukou we could at last be hired like city dwellers and contribute to our retirement pensions.

Moreover, the old village committees were maintained alongside the new Residents' Committees to ensure the transition of powers between the administrative structures of the village. In other words, the expropriation decision had been taken but not yet announced to the villagers, probably because it had not been approved administratively.

According to the documents I consulted, the administrative process to obtain authorisation for the requisitions began with requests to the Ministry of Land Management to build an ecological park and to nationalise the land, and lasted until 2004, when the requisitions were implemented. It was then that the authorities of the new Subdistrict office informed the "villagers" (38) that the land was to be requisitioned.

The village chief, elected in 2002 for a period of three years, then submitted his resignation according to testimony. The authorities of the district appointed a temporary leader from among the village committee members to ensure the end of the term, and normal village life resumed. Internal reports indicate that cadres from senior administrative levels came to present to the population of the island measures taken to facilitate employment assistance after relocation, ${ }^{(39)}$ while local officials received training to prepare them for the requisitions. The leadership of the village thus changed smoothly while propaganda work began surreptitiously.

Once the requisition program was put in place, ${ }^{(40)}$ a "task force" (gongzuo zu) moved into the empty fish factory at a distance from the village. Nobody really knew who had sent it, but it seems that it oversaw the practical management of the requisitions, giving orders to the village committee. ${ }^{(41)}$ Shortly after the arrival of the team, a symbolic change occurred: the interim leader of the village, the local secretary of the Communist Party and the cadres in charge of family planning set up their offices in the ancestral temple of the Huang clan. All the players in the relocation were then in place, ready to deal with the reactions of the people subject to requisitions. Moreover, the villagers were ordered to stop cultivating the land, which was no longer destined for agricultural use but for urban economic projects. Then came the announcement of the requisition, and the beginning of the interactions that would pit the category of local villagers against the local authorities.

\section{Limiting the sphere of action}

In October 2005, two months after the arrival of the Task Force, new elections were held in the village, but only the former members of the village committee were allowed to present themselves, and members of the security forces intimidated the village representatives, ${ }^{(42)}$ designating the "pre-

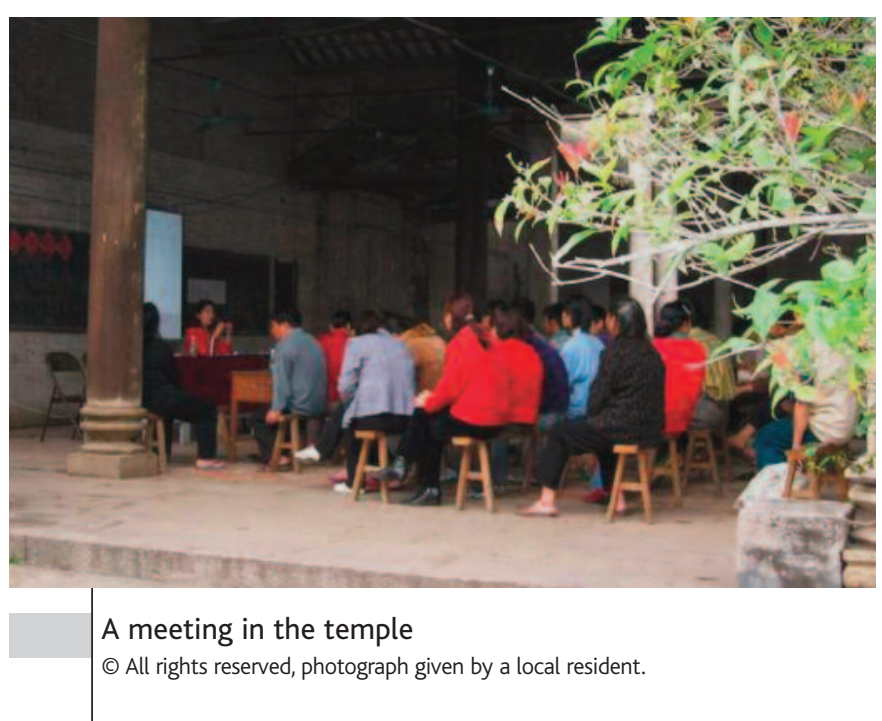

selected" candidate. On polling day, in front of all the villagers, policemen filmed the ballot papers as they were put into the ballot box. Some villagers decided to boycott the elections for fear of reprisals, which allowed the candidate supported by the authorities to be elected as the result of what was presented as a legitimate process.

Yuanfei Huang recalls: "I did not want to play their game, but neither could I take the risk of going to jail by voting for the person I supported, so I did not go to vote."

In November 2005, the government and the new leadership of the village signed an agreement on Xiaodao Island compensation and scheduled the requisition of the fields for the following month. Also, it was now forbidden for more than five people to meet together in the village. ${ }^{(43)}$ Several villagers protesting in groups were then arrested for criminal association. ${ }^{(44)}$ Finally,

38. In 2012, Xiaodao residents still speak of their peasant and village way of life, even though their status has not been that of farmers since 2002. We will therefore keep their terminology, in order to reflect the views of respondents as they still see themselves today.

39. The village of Xiaodao benefits from the measures implemented during the disappearance of rural hukou for the inhabitants of the borough of Xinjiao "To allow all members concerned [...] who request a certificate of unemployment to benefit within two years from free guidance from the government, three job offers, and free or low-cost vocational training." Cf. "'Chengzhongcun' gaizhi gongzuo huiyi" (Memory of the transformation of an "urban enclave") on the website of the cultural history of the city of Guangzhou: www.gzzxws.gov.cn/qxws/hzws/hzzj/hzzj/200910/ t20091016_14800_1.htm (consulted on 26 October 2012).

40. According to hearsay, the entrepreneur behind the project did not obtain the financing, but since the administrative procedures to use the land had already been carried out, the authorities proceeded with the idea of creating an "international ecological island," using developers able to invest in construction projects on the island.

41. Official documents highlight the regular visit to Xiaodao Island of the officials of the surrounding villages, employees of the local branch of the Party, and employees from different municipal services. Some cadres were probably dispatched from their original administrations to join the Task Force that lived on the island.

42. According to a villager, the "representatives of the people" (renmin daibiao) are elected by the villagers. They occupy an intermediate function between the village chief and the "masses," and they can participate in local meetings and make known the views of other villagers without being officials. Cf. Sylvia Chan, "Villagers' Representative Assemblies: Towards Democracy or Centralism?", China: An International Journal, Vol. 1, No. 2, 2003, pp. 179-199.

43. According to several internal documents, such as the "Note from the Guangzhou government about the progress and implementation of the work of requisition, destruction, and vacation of the Guangzhou International Ecological Island" published in September 2008, this decision is based on the "Criminal Law for the Management of Public Security of the PRC" (Zhonghua renmin gongheguo zhi'an guanli chengfachu) enacted in 2005.

44. I have not gathered any written evidence on this point, but two witness accounts converge. However, by virtue of the document mentioned in footnote 42, paragraph 4: "In the period of land requisition and destruction, each of the acts listed below shall be reprimanded [...] by the authorities concerned: disturbing the work of national authorities in carrying out their responsibilities; disturbing the normal progress of requisition of land and works; spreading rumours and confusion and generating conflicts; provoking fights in a group, looking for quarrels and deliberately causing disturbances to public order; stealing, plundering, or destroying public and private property." 


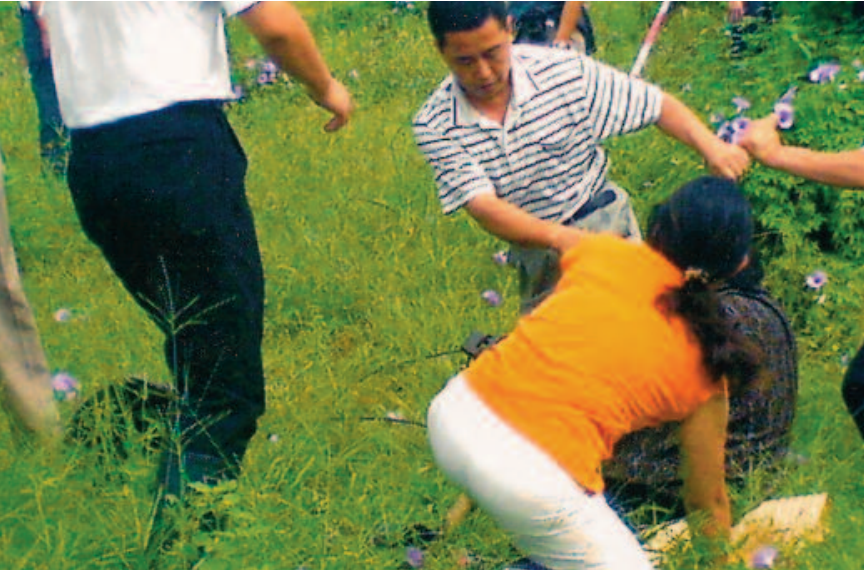

Land requisition

(c) All rights reserved, photograph given by a local resident

the villagers helplessly witnessed the uprooting of their fruit trees in December 2005. Only one old lady tried to intervene, but she was beaten and sent to the hospital. Villagers then warned her son not to go to the hospital, because he was wanted for protesting publicly against the authorities and risked arrest if he went there.

A report from the district to the municipality states:

Thanks to the coordination of activities between the local authorities, the central territorial development centre, and the departments concerned, the major difficulties have been overcome. Thanks to all types of effective measures that have been adopted and through propaganda and public discussions, 100 percent of the villagers have signed their requisition and agricultural land development agreements. ${ }^{(45)}$

Thus the authorities managed to get the signed agreement of residents while avoiding disturbances to public order.

\section{Monitoring of the Office of Letters and Visits}

Following these events, many villagers sent complaints to the Office of Letters and Visits ${ }^{\left({ }^{46}\right)}$ of the district and the municipality. The plaintiffs received the first official responses confirming that a review of the files found that the land requisitions in Xiaodao were carried out in accordance with national regulations. The people then tried to use several Offices of Letters and Visits at the municipal and regional levels, ${ }^{(47)}$ but the authorities dismissed the requests or referred the files to the lower levels on the grounds that the request was not their responsibility, and were slow to respond.

Some of the inhabitants realised that their complaints would not lead to a satisfactory conclusion and decided to raise money to send a group of complainants to the Office of Letters and Visits in Beijing, hoping to make their case to the head office of the administration, free from the corruption of the local authorities. When they got off the train, the plaintiffs were met by village cadres and Guangdong police. After two days of interrogation, they were sent back to village. ${ }^{(48)}$

The people most committed or able to take a stand were progressively isolated, while others became afraid or simply did not know how to pursue resistance any further. One of them commented: "We were confronted with

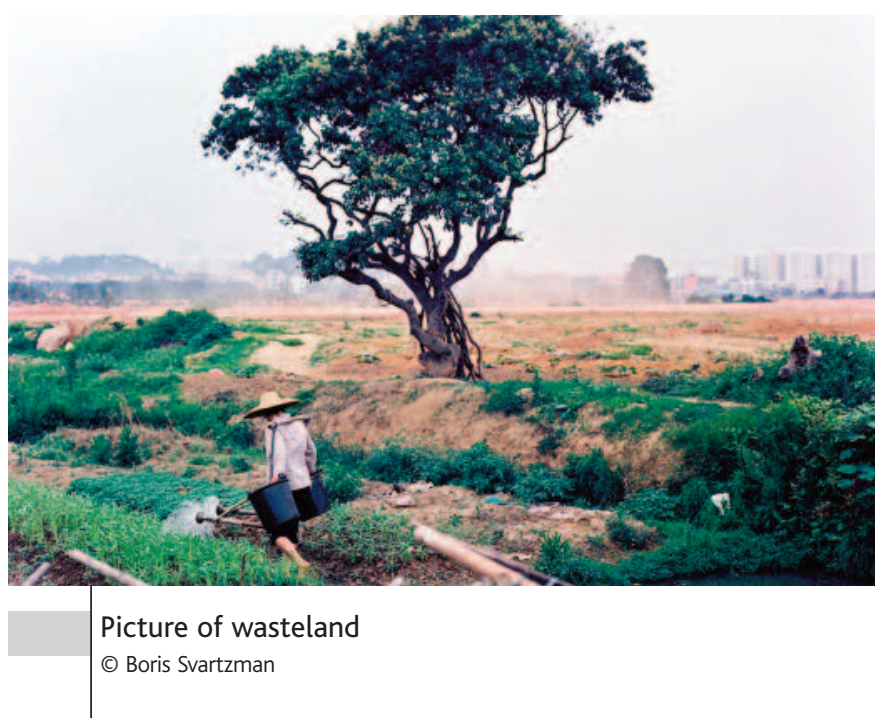

eviction professionals who had already displaced and destroyed dozens of villages around us."

Meanwhile, the propaganda work in the village continued, with public meetings where the expulsions were presented as a necessary step for the improvement of living conditions. Thus began a period of transition. The inhabitants, deprived of their agricultural land, all had to seek sources of income outside the village. Some people even found work thanks to measures implemented by the authorities of the district. Only a minority was then financially able and willing to take the risk of becoming actively involved in the resistance. However, most people circumvented the prohibition on cultivating farmland by cultivating for their own consumption any land by the roadside or outside the buildings that had not been previously recorded as "agricultural land." Despite the apparent calm after the failure of the collective complaints and the ensuing arrests, some of the inhabitants sought to show in this way that they were symbolically united against the authorities. ${ }^{(49)}$

\section{Monitoring of the legal route}

In the course of 2006, work on the tunnel began and the authorities demolished two houses belonging a Huaqiao couple who had invested in the

45. See "Xiaodaodao nongyongdi Shunli yijiao" (Xiaodao Island farmlands successfully transferred), Report of the Bureau of Land Management and Housing of Haizhu District, 6 December 2005.

46. All government authorities and the CCP are supposed to have an office of Letters and Visits (whose central office is located in Beijing), where people can report grievances, injustices, etc., to higher authorities without going through the legal route. The rule is that the complaints are written at the local level and then progress up the levels to the higher authorities when claims are rejected. Complainants then feel compelled to go to the offices to press their demands. To limit the extent of group visits, regulations limit to five the number of spokespeople who are actually received. See the work of Isabelle Thireau et al., Les ruses de la démocratie, op. cit. The articles by Lianjiang Li, "Political Trust and Petitioning in the Chinese Countryside," Comparative Politics, Vol. 40, No. 2, 2008, pp. 209-226; and Ying Xing, "Les 'visites' collectives des paysans auprès des autorités supérieures" (The collective 'visits' of peasants to superior authorities), Études rurales, No. 179, 2007, pp. 155-168 also describe some of the points mentioned.

47. They addressed such a letter to the municipal land management and housing administration. But they did not know then that this administration was responsible for "overseeing the work of requisitions in times of tension, of heavy responsibilities, of complication of situations related to land, and other situations where some villagers have not understood the situation," "Summary of meeting with the Mayor of Guangzhou," 5 September 2007.

48. Several accounts are confirmed by more recent complaints, which also denounce this episode.

49. On everyday practices as a source of freedom, cf. Michel de Certeau, L'invention du quotidien. Tome 1: Arts de faire (The invention of daily life. Volume 1:The Arts de Faire), Gallimard, 1990; Marc Bessin et al., "Les armes du faible sont-elles de faibles armes?" (Are the weapons of the weak weak weapons?), L'Homme et la société, No. 143-144, 2002, pp. 3-11. 

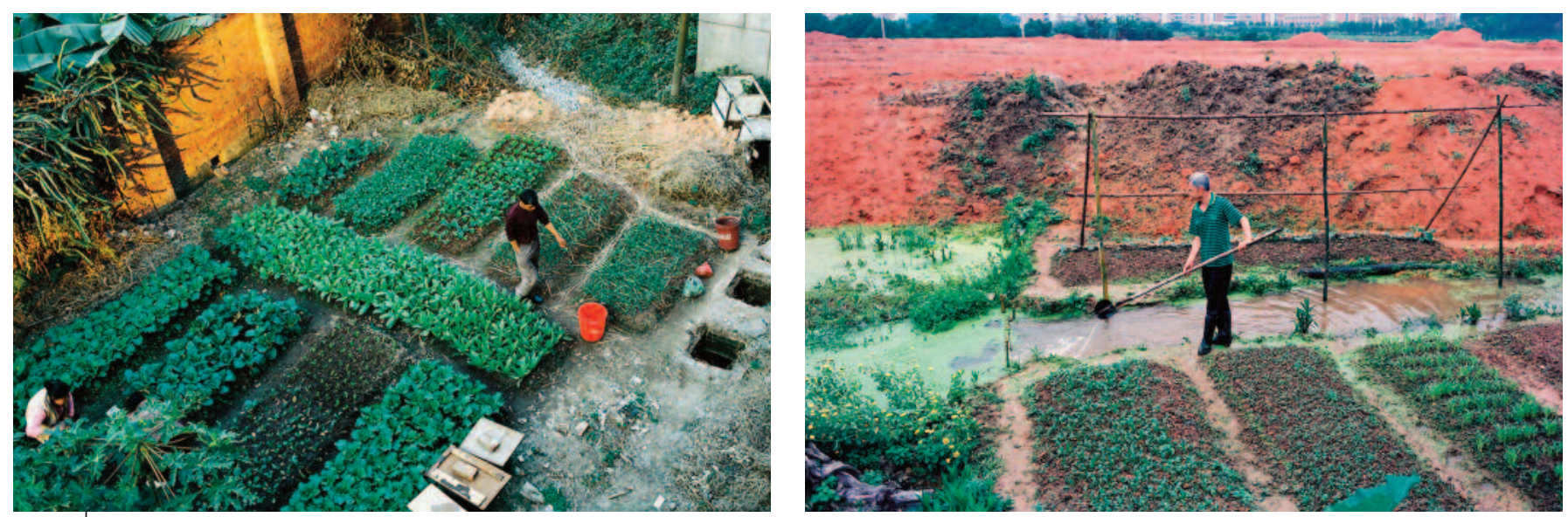

Plots of land

(c) Boris Svartzman

construction of the school, and a six-storey building belonging to Huang Changliang, a representative of the villagers who had started investing in real estate on the island. Seeing the failure of collective grievances, the three owners decided, separately, to resort to the services of two firms of lawyers in Beijing in order to sue.

Counsel for the villager filed a complaint against the district authorities for the destruction of his client's house, but he added a second charge that called into question the requisition of the village's collective land. He stated that the villagers cultivated a total area of more than 2,000 mu(50) and denounced the calculation of compensation on the basis of 72 mu of "agricultural land," while the rest of the collective lands managed by the village committee were transformed into natural non-agricultural land, namely $269 \mathrm{mu}$ of "forest" and 1490 mu of "park," which are part of the "10,000 Fruit Tree Park" of the district. Agricultural lands are better compensated than parks and forests, because they are a means of survival for the villagers.

Huang Changliang's father-in-law, who is almost 70, furiously recounts:

Originally, the 2,000 mu of agricultural land were used for food crops. I was the first inhabitant to plant fruit trees in the 1980s, to enable my sons to go and work in the city. Then all the peasants in the village did the same, and now people dare to say that the village had only a few mu of agricultural land, which in reality corresponded to the only vegetable plots remaining on the island in 2004.

According to the arguments put forward by the lawyer, however, this decrease in surface area was mainly a means for the authorities to circumvent the law on the preservation of agricultural land at local level. ${ }^{(51)}$ They thus accuse the local authorities of "by-passing the law by cheating on the amount of agricultural land and usurping the name of the government to intimidate the villagers." (52) On 25 March 2007, the lawyer, who had gone down to Guangzhou to plead the villagers' case, was reported missing. According to some villagers, he was kidnapped by the local authorities. Two days later, he reappeared, having been sentenced to a year in prison for illegally consorting with a prostitute in his hotel room. ${ }^{(53)}$ The villager who had hired the lawyer was not arrested, but lacking a lawyer, the lawsuit against the district authorities was dropped. ${ }^{(54)}$

As for the two lawsuits brought by the Huaqiao couple after several appeals, the High Court of the Guangzhou area in 2010 recognised a procedural defect and requested a retrial, but in 2012 this had still not taken place. Instead of direct repression against the Huaqiao, the authorities seemed to be delaying the trial in order to avoid discussion. However, their lawyer, who had meanwhile agreed to defend other villagers, stated that he had received threats from various authorities for disorderly conduct in public. ${ }^{(55)}$

\section{The manipulation of an incident}

Three days before the arrest of the lawyer, a truck on the tunnel project passed perilously close to a villager. There followed an altercation between the driver and nine villagers who were present at the scene. Construction workers then arrived, equipped with metal bars. Several farmers were injured, two men remained in a coma for several months (including Huang Changliang's father-in-law), and a third person died of his injuries. In addition, four villagers involved in the fight, including Huang Changliang's brother-in-law, were arrested for disturbing public order. They were sentenced to over a year in a re-education work camp, where they were reportedly denied any visitors. ${ }^{(56)}$ Moreover, there is no evidence that the workers who beat them with metal bars were arrested and tried.

Shortly after the incident, the authorities offered to release the four prisoners in exchange for signing the relocation agreement. In addition, they

50. A mu is equivalent to 666.7 square meters.

51. According to He Bochuan: "On 1 July 2002, in order to slow the pace of requisitions, the Ministry of Land and Resources ordered that as from 1 July 2003, any project involving building land would have to pass through a system of advertisements, tenders, and auctions. [...] The result, for 2002 on a national level, was over 140,000 violations of the law, or 50.5 percent more than in 2001. And in 2003, [...] there were 168,000 illegal cases, concentrated mainly in the first six months of the year." "La crise agraire en Chine. Données et réflexions," op. cit., p. 123.

52. The villagers include these terms in several complaints, such as the one entitled "Jiujiu women!" ("Save us!") addressed to "The Respectable Discipline Committee of the CPC," 21 February 2009.

53. Information confirmed by the website "Weiquan wang," cf. "The lawyer who helped farmers on the Island Xiaodao in Guangzhou to defend their rights was denounced and arrested for frequenting prostitutes" (Xiezhu Guangzhou Xiaodao cunmin weiquan lushi bei zhi dangju piaochang Juliu), 18 July 2007 (missing web page, last accessed in May 2010).

54. There appears to be no evidence confirming the amount of agricultural land previously held, but the inhabitants have a 1998 document that planned the preservation on the Xiaodao Island of $475 \mathrm{mu}$ of farmland, proving that the figure of $72 \mathrm{mu}$ was well below the reality.

55. "The inhabitants of Xiaodao refuse at all costs to sacrifice their ancestral temple. Some denounce the control of the official lawyer," 6 January 2009. Weiquan wang website (missing page, last accessed on May 2010).

56. I met two people who had spent more than a year in jail, but they remained silent on the type of prison where they had been, preferring to let the other people in the room speak for them. Only one person said about their incarceration: "Even the prison guards had pity on us. They knew that we weren't criminals, and that we had nothing to be ashamed of. We were more free in prison than on our island." 


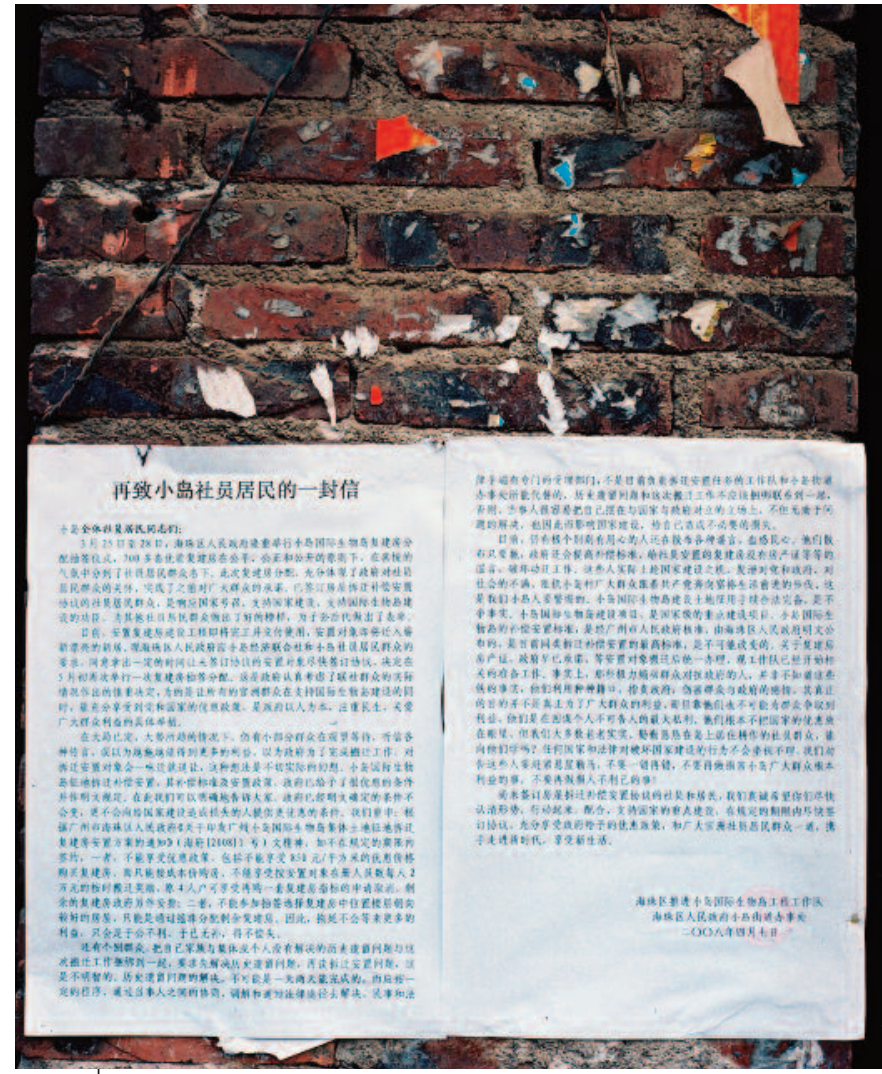

The letter to the residents of Xiaodao

(c) Boris Svartzman

offered 900,000 yuan in compensation to the family of the deceased. But the father refused the money as an attempt at a cover-up, and tried to commit suicide by swallowing fertiliser. The peasants found him unconscious and saved his life, but "this did not awaken the authorities," as they wrote in several complaints made to local authorities. They denounced the blackmail attempts and demanded that "the truth be rectified" about the arrests and the death. Local authorities then responded, as in this letter from the Xiaodao Subdistrict office sent in April 2009, two years after the events:

[...] A member of the Xiaodao Economic Union, due to a heart problem, had a sudden heart attack resulting in his death (according to the medical diagnosis that the Department of Medicine at Sun Yatsen University agreed to carry out especially for this case). ${ }^{(57)}$ Those involved in the fight who committed illegal acts have been reprimanded by the law. There is therefore no connection between the death of this villager and the work of land requisition.

However, this episode reinforced the shared sense of injustice among the villagers. Sixty of them tried a few weeks later to go to Beijing, travelling in several groups in order not to be noticed, but they were arrested, some spent a year in jail, and their names were added to a blacklist. ${ }^{(58)}$ It is unclear whether the fight was provoked or if it was just a combination of circumstances, but the exploitation of this incident helped radicalise the repression against the villagers.

\section{The relocation approaches}

A few months later, in January 2008, a "Notice of Relocation" was posted in the village. Two hundred sixty-four villagers signed a request for a collec- tive audience. Only five representatives of the villagers were allowed to express themselves and 27 people were able attend but could not speak. Thirteen members of the government and two journalists listened to what they had to say. The farmers asked in particular to see the documents proving the validity of the requisitions and the methods of calculating compensation. The cadres present stated that the change of hukou, which took place in 2002 , does not provide for the transformation of rights to use buildable land in the country into ownership rights, ${ }^{(59)}$ which are reserved for the urban market. The houses, even those more than 300 years old, were considered "illegal" and must be destroyed.

In April 2008, as the draw for the allocation of new housing approached, another document was posted in the village:

\section{Letter to the residents of Xiaodao ${ }^{(60)}$}

From 25 to 28 March 2008 there will be a ceremony to distribute new housing on the International Ecological Island of Xiaodao. [...] 700 lots will be redistributed with joy. [...] Those who have already accepted compensation for the loss of their homes are worthy men who by their actions support the construction of the nation. [...] May they serve as models for the other residents. [...]

Residents of Xiaodao [...] must apply in time to take advantage of discounts offered by the Party. This is a practical approach to defend the interests of the masses. [...] That is why Humanism is at the heart of the government's concerns. [...]

Those who do not sign in time will not benefit from the reduced rate of 850 yuan per sqm for the purchase of their new apartment, or the 20,000 yuan reward for a departure in time; likewise they will not be able to choose the orientation or which floor their apartment will be on. That will be determined by the draw. [...]

No law and no state can sit idly by in the face of harmful acts. We advise those people [who spread all kinds of rumours] to stop before it is too late! [...]

For those who have not yet signed the compensation agreements: We expect you to cooperate and hope to come into this new era hand-in-hand with you. [...]

- The team of engineers to promote the International Ecological Island of Xiaodao. [Tuijin xiadao guoji shengwudao gongcheng gongzuodui]

- Subdistrict Office of The People's Government of Haizhu District

57. According to the authorities, the hospital of Sun Yat-sen University carried out analysis of the death without an autopsy. It seems that the first violent demonstrations in the village of Wukan, in the Guangzhou area, also started after the death in custody of a representative of the village, which has been presented as a heart attack by the same hospital, more than 300 kilometres from Wukan. See iSunAffairs, op. cit.

58. Several people mentioned this list, saying it is transferred to a national electronic file that prevents them from buying plane and train tickets, and makes it possible to follow them whenever their identification is recorded in a centralised system. One of them was arrested one day on the way to a hotel, because the police received an automatic signal indicating the presence in the city of a blacklisted person. They interrogated him for several hours, thinking he was a criminal. When they got to the police station, they realised that there was a phone number included in the file. It was that of the "Task Force" to be contacted when a person went to Beijing to bring a grievance. Laughing, this person told me that the police then exclaimed: "Oh! Is that all?", and gave him admission to a foot massage parlour, where he was able to spend the night.

59. On this point cf. Wang Hansheng and Shen Jing, "La formation des droits de propriété dans les campagnes chinoises" (The creation of property rights in the Chinese countryside), Études rurales, No. 179,2007 , pp. 193-212.

60. Excerpts translated by the author 
Those residents most involved in the fight against the requisitions who had not been imprisoned understood that they were directly threatened. Those who could not resign themselves to signing then took flight. ${ }^{(61)}$

Having to go into hiding, they tried to alert the media at a distance on the situation in the village. Changliang recounts that an English journalist with the BBC had agreed to investigate, but he was met on the island by plainclothes police with fluent English, who forced him to leave. Several articles touting the merits of the proposed Ecological Island and the improvement of the living conditions of peasants were published, but only a single Chinese journalist published an article that the villagers would consider to be "objective." (62) During my last visit, a villager let slip: "Now that you're a friend, we can tell you that we paid the journalist over 20,000 yuan in exchange for his investigation." (63) The article served as evidence that they cited in a large number of complaints, but in 2012 they admitted that the article had had no real impact in their attempts at resistance.

In May 2008, a month after the "Letter to the inhabitants of Xiaodao," a new dramatic event occurred: residents learned that they would not be able to take part in the Duanwujie Festival, during which the Dragon Boat festivities take place. During these celebrations, men go for days at a time to the "brother villages" in the area, which are often members of the same clan, to maintain the ancestral ties between villages. ${ }^{(64)}$ Xiaodao residents had two boats, one of which was said to be a hundred years old, and a third clan boat reserved for Chinese emigrants who return to the village for the ceremonies. However, a few days after the ban on participation in festivals, residents found the three Dragon Boats destroyed. The villagers suspected the Task Force of having committed this offense, but no perpetrator or witness of the destruction of boats could be found. According to one resident:

Our village had qualified to compete in a dragon boat race at the municipal level. They destroyed the dragon boats for fear that we might seize this opportunity to display banners in front of the cameras and the public.

Without a boat, they were excluded from the competition without the authorities having to justify a ban on competing. The authorities thus showed an ability to use timely means of repression for each situation while striking at the identity of the village community. Some people even say they thought at the time that "they wanted to erase the name of Xiaodao."

\section{A "successful" relocation}

In the course of 2008 , the authorities obtained agreement to relocate the majority of the residents, and the collective move took place in October. ${ }^{655)}$ The village authorities also left the island and moved into their new offices in one of the two blocks of flats. A hundred people who refused to sign the agreement then stormed the temple of the ancestors, in which they took refuge, but they could not prevent the authorities from demolishing their homes. They lived without electricity for several weeks. Monitored in their every move outside the island, those who worked in the city saw pressure brought to bear on their employers. ${ }^{(66)}$

In the year following the eviction, the majority of the resisters gave up the siege on the island; some signed the eviction agreement, while others preferred to rent in the city in order to continue their resistance at a distance. There were only 20 people left in the ruins of the village. Moreover, the villagers in prison were released, and those who had fled were able to return, since the destruction of the village was complete.

Six months after the move, the Xiaodao cadres were commended for conducting the operation calmly. The inhabitants had all received their ownership documents, marking the transition to modernity through access to private property. A ceremony was organised for the occasion. A meeting was held between the cadres of the Residents' Committee and the military of the district, after which they spelled out the "lessons from the experience of the eviction of Xiaodao" marking "the end of the river crossing." (67)

Complaints thus remained geographically limited to the surroundings of the island of Xiaodao. No more than a few complaints were able to reach up as far as the municipal and regional governments, but the relocation of the village was carried out without any public excesses or any effective media coverage of the struggle.

\section{Revolts without social movement}

The authorities in charge of moving the village compensated the islanders differently according to their category (urban dwellers, former farmers, Huaqiao), which resulted in different patterns of complaints and modes of resistance. Repressive measures were then adapted to each category of people. Thus, on the island itself, the struggle against expropriation was divided between the different categories of people, as if the expropriations were being carried out in different places and for different reasons.

Moreover, we have seen that repression intensified during the periods of requisition of collective property, first of the land, then of the village, while it was more diffuse at times when the struggle was restricted to specific interests, as in the case of the last resisters once the collective relocation was completed. This was also the case of the workers who fought only for the defence of their homes, to which they held an urban title, and not against the closure of the factory or against the "Ecological Island" project. In return they were not subjected to any physical violence.

It is difficult to see how this resistance, however intense, could form a social movement, as it was not even coordinated among the inhabitants of the island. (68) Most complaints were attempts to renegotiate the compensation provided by the authorities, but almost no resident questioned the

61. Changliang then left to work for an NGO based in Hong Kong, which helps the education of poor children in rural areas, and did not return to Xiaodao until a year later, once the eviction was complete.

62. "Guangzhou guoji shengwudao bei zhi manbao qianmu gengdi" (Xiaodao International Ecological Island criticised for concealing more than 1000 mu of farmland) Huaxia shibao (China Times), 10 May 2008, p. 5.

63. This earned him a vociferous telling-off in Cantonese.

64. The Dragon Boat festivals were banned during the Cultural Revolution. On the history of dragon boat racing, cf. Andrew Chittick, "The Song Navy and the Invention of Dragon Boat Racing," Journal of Song-Yuan Studies, Vol. 41, 2011, pp. 1-28. On the observation of tensions on the ground around these festivals, cf. Boris Svartzman, "Cérémonies de Bateaux-Dragons" (Dragon boat ceremonies), Carnets du Centre Chine, June 2012, http://cecmc. hypotheses.org/?p=6952 (consulted on 26 October 2012).

65. Residents had to pay for the moving trucks that were made available to them.

66. For example, one of the resisters, who had to travel in the course of his work, told how members of the public security apparatus asked his boss to deprive him of his company car, as it was becoming too complicated to follow it. Acts of vandalism then took place at night in the premises, which came to an end when he chose to leave his job.

67. Report of the Subdistrict Office, 26 December 2012.

68. According to Chen Yingfang, "Expecting to see the emergence of a political movement to change the system, based on the expectations and demands for housing of the displaced, does not correspond to the reality of civil society"; "Légitimité, rationalité et stratégies politiques: les fondements du 'miracle urbain chinois'"' (Legitimacy, rationality and political strategies: The roots of the "Chinese urban miracle"), Terrains \& travaux, No. 16, 2009, p. 132. 


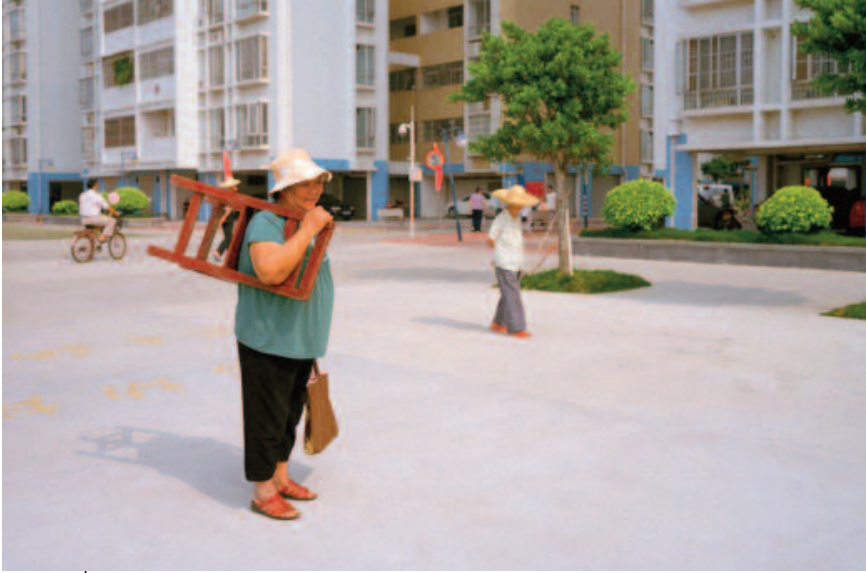

An inhabitant standing in front of the new blocks (c) Boris Svartzman

proposed expulsion in written complaints. The only villager who filed a lawsuit on this question (with the help of a lawyer) opposed the requisition of collective village land without questioning the expulsion of other categories of people. The authorities thus managed to transform the opposition of the inhabitants of the island into an accumulation of resistances related to social and individual categories, which only marginally disrupted the social order of the island. The Office of Letters and Visits played the part of providing an outlet through which dissatisfaction could be legitimately expressed, but never turned into a space for legitimate complaints against the government.

Residents understood, however, that the only hope of getting the attention of the authorities was to remain united in order to produce a mass effect (so that complaints did not come from isolated agitators, but from the group as a whole). However, at no time did the various categories of inhabitants unite against the proposed Ecological Island. This division of the population thus became the frame of reference, respected by the people, in which actions were to take place. ${ }^{(69)}$ Resistance thus seemed to be limited by the authorities both geographically and in the form it took.

While occupations of public or private spaces (sit-ins) are generally effective means of pressure on the authorities, ${ }^{(70)}$ here they were the result of a struggle constrained by the legal framework. The authorities were able to impose on the inhabitants committed to resisting the requisitions a mode of action, holding out in their own homes, which was not necessarily the one that people would have chosen if other forms of pressure were not severely punished. This is perhaps the central feature of the crackdown, which was not to eliminate dissenting voices, but to confine them in spaces that allowed the expression of complaints (by sending complaints or sitting-in in one's own house) while preventing the struggle from transcending the private sphere. Despite collective dissatisfaction, resistance was reduced to a personal commitment, deprived of any public action.

Those who then tried to negotiate and enter into the process of writing grievances faced a crucial choice: either to attack the project supported by the local government directly - but they must bear the consequences of the repressive machinery - or to express their dissatisfaction without calling the relocation into question. Faced with this second type of complaint, the local authorities adopted an attitude of partnership in which dialogue is possible, while trying to gain acceptance of the public interest. Although consent was obtained by methods that cast doubt on the le- gitimacy of the authorities, the latter cannot be said to have acted illegally, and any future complaint is theoretically defused. The highlight of the requisition was therefore not based on mere repression by the government against the resistance movement, but rather on the strategy of leading all the inhabitants to sign the original agreement. Objections to evictions in China do not therefore call the government into question; they fit into the process of urbanisation as an element that is now part of the system.

In our view, the case of Xiaodao is revelatory of the methods used in a large number of forced requisitions in China, both in the city and in the country. ${ }^{\left({ }^{11}\right)} \mathrm{A}$ number of tensions related to expropriations are relayed, especially in the Chinese social media and the international press. Indeed, because of the violence by the authorities against groups of individuals who resist at all costs against their expulsion, the particularly virulent demonstrations produced are then often raised by outside observers to the level of a growing ${ }^{(72)}$ social movement that reflects a desire of the Chinese people for empowerment in the face of local cadres. ${ }^{(73)}$ But most of the resistances are isolated from each other because of their local nature, thus making repression of these demonstrations easier. The publicised cases constitute exceptions in light of the millions of people evicted every year whose resistances are ignored. In addition, people who engage in the defence of townspeople and farmers facing eviction are usually arbitrarily arrested. ${ }^{(74)}$ Although there is awareness at the national level of the seriousness of the evictions, the accumulation of resistance to expropriation does not make a social movement.

However, there exists a context of social protest that could at any time form the basis for a social movement. First of all, the formal approval of the people who signed the expropriation agreement does not prove that the tensions are resolved permanently. To return to the case of Xiaodao, for example, we observed the emergence of new complaints in the blocks of flats, which show that the dissolution of the village community did not resolve the feeling of injustice, even four years after the relocation.

69. Zhang Lun writes: "Unlike in many Eastern European countries, reform is initiated and promoted by the ruling elites. Going beyond the existing legitimate framework is unimaginable at the outset, and remains difficult thereafter"; "Changement social et mouvements sociaux" (Social change and social movements), Cahiers internationaux de sociologie, No. 122, 2007, p. 11.

70. Susana Bleil, op. cit.; Frédéric Vairel, "L'ordre disputé du sit-in au Maroc" (The disputed order of sit-in in Marocco), Genèses, No. 59, 2005, pp. 47-70; Étienne Penissat, "Les occupations de locaux dans les années 1960-1970: processus sociohistoriques de "réinvention" d'un mode d'action" (Occupations of buildings in the 1960-1970: Sociohistorical process of "reinventing" an action mode), Genèses, No. 59, 2005, pp. 71-93; Denis Merklen, "Le quartier et la barricade: le local comme lieu de repli et base du rapport au politique dans la révolte populaire en Argentine" (The neighbourhood and the barricade: The local scale as a retreat place and a base for the political relations in the Argentinian popular revolt), L'Homme et la société, No. 143-144, 2002, pp. 143-164.

71. Cf. "Standing their ground. Thousands face violent eviction in China," Amnesty International, 2012, www.amnesty.org/en/library/asset/ASA17/001/2012/en/976759ee-09f6-4d00-b4d84fa1b47231e2/asa170012012en.pdf (consulted on 13 January 2013).

72. On this subject, Zhang Lun refers to a "'protest movement' across the whole country to demand the implementation of existing laws and enforcement of laws to defend their rights," art. cit., p. 23.

73. The many analyses of the case of the village of Wukan show this state of mind clearly. Cf. for example iSunAffairs, op. cit:; Sun Liping, "Why Wukan will remain a one-off," The Observer, No. 557, 2012, pp. 45, www.eeo.com.cn/ens/2012/0425/225257.shtml (consulted on 16 August 2012); Le Monde, "Le 'laboratoire' de Wukan galvanise les milieux progressistes en Chine" (The 'laboratory' of Wukan galvanises the progressive milieus in China), 5 December 2011; New York Times, "Village Revolts Over Inequities of Chinese Life," 14 December 2011; The Telegraph, "Wukan: Rebel Chinese village prepares to hold extraordinary elections," 31 January 2012.

74. The arrest of the lawyer hired by the villagers is not an isolated case. See for example Human Rights Watch, op. cit:; Amnesty International, "Defenders of the right to housing: Zheng Enchong," 5 July 2006; The Guardian, "Chinese dissident jailed for five years after human rights petition," 25 March 2008; Human Rights in China, "Land Rights Activist Yang Chunlin Released," 6 July 2012. 


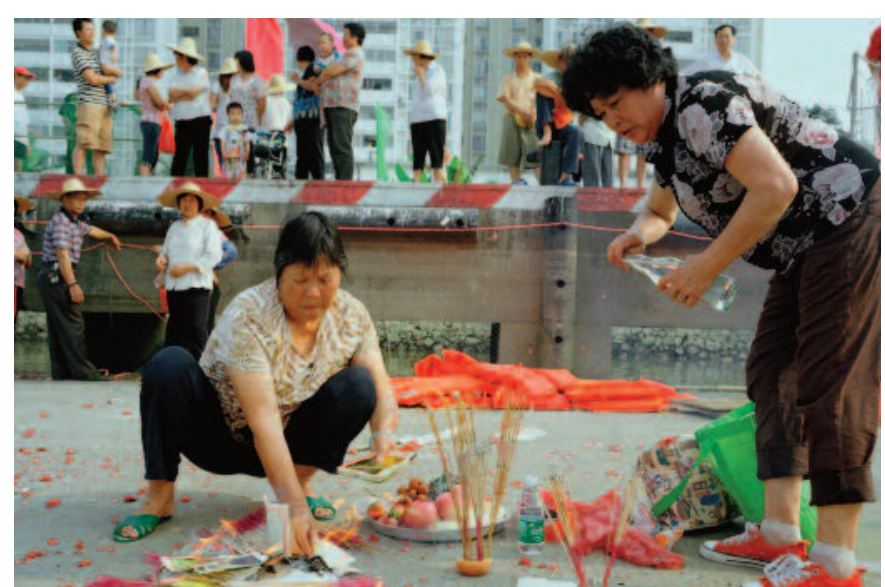

Ceremony in front of a block of flats

(c) Boris Svartzman

\section{Initial adaptation to the urban environment}

The urban transition of Xiaodao Village began with the change of hukou in 2002, and ended six years later with the move into the apartment blocks, concluding several years of collective resistance. However, 40 people have not signed the eviction agreement, including 20 who still live on the island, amid the ruins of the village, in the houses of the Huaqiao hidden by fences, and some of the population living in the new housing is engaged in new demands.

\section{Symbolic resistance}

After an unsuccessful first attempt at immersion in the apartment blocks in 2009, I was able to witness moments of community life through the resumption of the Dragon Boat festivals in 2011 and 2012. After the suspension of festivals since the destruction of the boats in the village in 2008, the new committee of Xiaodao residents made a gift of two new boats in 2011 (with a capacity of 80 people each) to the former inhabitants of the village. On the day when the Brother Villages were invited, the Residents' Committee also organised a meal for more than 1,000 people in front of the apartment blocks, where ceremonies are now held. According to some witnesses, a hundred cadres and police attended, sitting at tables that had been set up on the parking lot of the residence.

While these festivals were the subject of growing interest on the part of the inhabitants of the region, who packed the banks of the river to see the rowers pass, three groups of people opposed to manipulation by the authorities of their traditional festival then clubbed together to buy their own Dragon Boats (with a capacity of 40 people) and held, in the ruins of the village, in the temple of the ancestors of the Huang clan, their welcoming ceremony for the Brother Villages "as is traditional." (75) The Subdistrict authorities allowed the festivities to happen simultaneously in two places, although the inhabitants saw it as an act of resistance. One of them even said to me in a joking tone: "We can say that we are a splinter party."

However, residents living on the island were ordered not to let me attend the festivities, citing security reasons, and many of my interlocutors were questioned on this occasion by the police on the reasons for my presence. In 2012, I was also forbidden access to the training that preceded the festivals even though it was taking place on boats purchased by individuals.

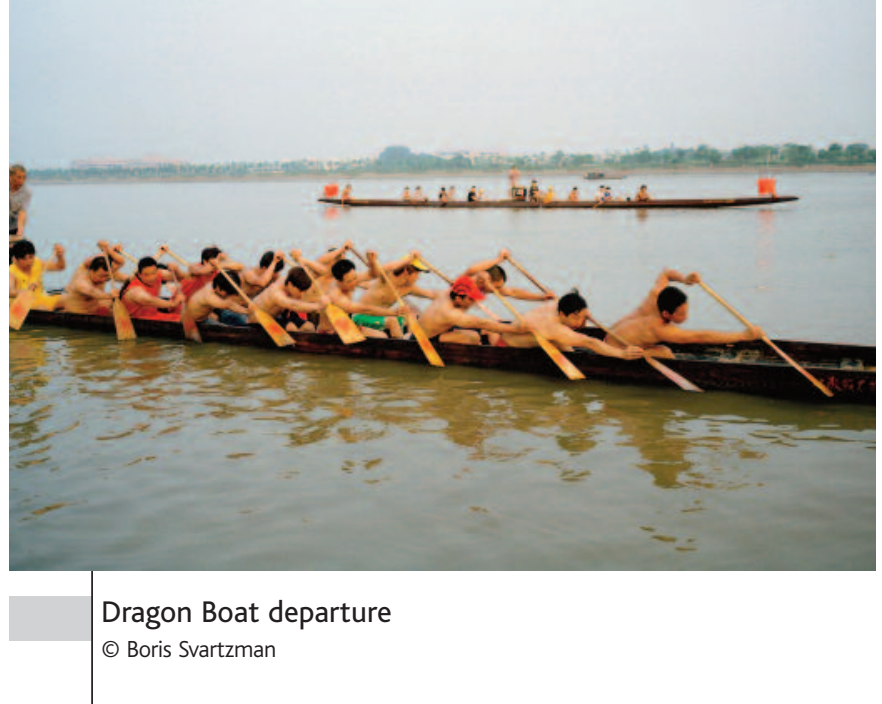

One of the residents, upset about this, told me: "They say that the village cannot be responsible if you have an accident, but they are our boats. Yet nobody prevents us from having you as a passenger in our cars even if you risk an accident."

But other villagers saw that the authorities feared that my presence might allow the divulging not only of the presence of the last households that resisted eviction, but also of the new complaints emerging. One said to me discreetly: "You must understand that some people cannot sleep at night while you're here."

In fact, I met a resident working in another city ${ }^{(76)}$ who told me that he returned to Xiaodao during the Dragon Boat Festival in order to show other people that resistance could continue even if the village had been destroyed: "It's like boat races: we must be united to move the Dragon Boat, and the more our movements are coordinated, the faster the boat moves."

\section{An enduring feeling of injustice}

Some people have decided to start carrying grievances to higher authorities because they feel they have been cheated on the value of their houses on the island, and are deeply dissatisfied since their relocation. In addition, residents have returned to mass demonstrations, to demand a new election within the Residents' Committee, as well as control of the new economic and political structures of the "village." Indeed, despite the status change from rural residents to urban residents, Xiaodao inhabitants did not gain access to the social services reserved for urban residents, which further exacerbated the sense of injustice linked to their relocation.

To compensate for the loss of agricultural land, which was collectively owned, farmers received compensation high enough to finance the purchase of approximately one apartment per family. However, the village committee, which managed the collective land, was also granted compensation that was used to purchase land in the city for land transactions, primarily leasehold. In order to maintain a collective management structure for the

75. Cao Dan also shows the importance of the Dragon Boats in village culture, and how people use the opportunity of this event to return to their native place. Cf. Dragon Boat, op. cit.

76. This resident has not signed the eviction agreement. He stays with his sister in Xiaodao because he is on the blacklist and has already been arrested when registering at a hotel. He called a friend who owns a car with tinted windows to take me discreetly to a restaurant where we could talk, away from the block of flats. 
new land, the "Xiaodao Rural Cooperative" was formally changed to the "Xiaodao Economic Union" (Xiaodao lianheshe), managed as a corporation whose profits are paid to shareholders. ${ }^{(77)}$ In 2002, the date of the change of hukou, every adult villager received a share, and people over 60 received two shares.

According to testimony, the other villages in the area also saw the creation of Economic Unions, and the rule was that they would manage a land area of about 10 to 15 percent of the land formerly owned by the village. ${ }^{(78)}$ The Xiaodao Economic Union acquired four lots with an area equivalent to approximately 10 percent of the land formerly owned by the village committee (about $200 \mathrm{mu}$, including $20 \mathrm{mu}$ of land that was granted on the island of Xiaodao). But only one site was being exploited in 2012, bringing in 250 yuan per share. Although agriculture was unprofitable from a financial point of view, it was an integral part of the domestic economy as an independently managed safety net. In contrast, the new organisation of collective land makes land management opaque, and people have no idea of the actual returns.

Moreover, the authorities established access to a minimum pension for villagers over 60 , and have set lower contributions for people over 45 so they can contribute more easily for the 15 years required, but younger residents must find a job in order to contribute. In addition, a large number of them have worked in the city since the 1980s without being able to contribute to social benefits. ${ }^{(79)} \mathrm{A}$ resident who is approaching 50 comments:

I worked for over 20 years in the city. Now that I have trouble finding a steady job, because it's becoming more difficult to deal with the competition of young migrants who accept low wages, I no longer have any land to survive on, because of the expropriation!

Thus, despite the change of hukou, only a small number of the inhabitants of Xiaodao have access to social protection, ${ }^{(80)}$ while they all have a - minimal - income from the new "collectively" managed land, which is not available to residents in the same neighbourhood who were not members of the former village committee.

However, voices are beginning to be heard requesting the funding of pension contributions for all the residents and democratic elections for the residents of Xiaodao, which have been suspended since the last elections in 2005 after the resignation of the chief of the village (local elections are supposed to take place every three years). But the Subdistrict Office responded that because of "the administrative work necessary to complete the transition from a rural to an urban system," (81) the higher authorities have authorised the suspension of elections. Moreover, they claim to have established a system of "control over finances, public affairs, and government affairs. Violations of the law and regulations that are discovered during the screening process will undergo legal examination [...], the residents who signed the requisition, destruction, and relocation agreement therefore have no reason to complain." (82)

Some people then took an even greater part in the collective grievances, and demonstrated not only in front of the offices of the Residents' Committee, but also of the District and the city of Guangdong, where they did not hesitate to confront government cadres. ${ }^{83)}$

In other words, the tensions that emerged were intimately linked to the former management framework of the rural community, despite the dismantling of the administration put in place in the early days of the communist regime. In addition, the new administrative structures, which symbolise ac- cess to a capitalist economy, are in fact also forced to adapt to the new forms of urban organisation they themselves have brought about.

This situation illustrates the blurred territory that persists in the distinction between collective interests inherited from the former village cooperatives and the stranglehold of the state on the national development of a capitalist-style economy. An inhabitant explains his experience: "Now that our hukou is 'non-rural,' we are neither rural nor urban. What is our identity, exactly?" Although he seems not to know that the term urban hukou does not exist, ${ }^{(84)}$ he reveals what he really thinks: "We are not like other urban dwellers." From this gap is emerging a new urban class looking for benchmarks and increasingly demanding its rights.

The commitment of these residents, ready to defend their interests despite the repression they suffered before the eviction, makes it possible to understand why the authorities maintain such control over the residents in the blocks of flats after their move into the buildings. The intensity of these tensions, rather than being opposition to the regime, is now part of the very process of relocation and adjustment of villagers to urban settings, which the authorities cannot deny. It is difficult to predict the direction events will take, when and how the remaining inhabitants who are holding out on the island will be expelled, whether the income from other development land will suffice to meet the demands of new residents, if the residents will manage to elect one of their own who will defend their interests, etc. What is certain, however, is that all these events will be revelatory of the political context in China. As one resident put it: "Xiaodao, is not the whole of China, but everywhere in China there are the same problems as in Xiaodao."

The displacement of Xiaodao villagers into new apartment blocks gives us a fairly accurate picture of the movement of a village, but also of how resistance to this move marks the transition of the rural population and its structures of government to an urban setting.

\section{Translated by Michael Black.}

I Boris Svartzman is a doctoral research fellow at the EHESS-CECMC (School for Advanced Studies in Social Sciences - Research Center on Modern and Contemporary China).

EHESS-CECMC, 190-198 avenue de France, 75013 Paris, France (boris.svartzman@gmail.com).

77. Shares can change hands, but the number of shares is determined by the number of inhabitants at the time of the eviction and cannot be increased in case of births or decreased by deaths.

78. At the time of writing this article, I had not been able to find information other than witness accounts of the functioning of these economic unions. However, Hou Xiaoshuo has suggested the term "community capitalism" to describe the new economic structures that allow village communities to enter the market without abandoning collective interests. See her article, "From Mao to the Market: Community Capitalism in Rural China," Theory Culture Society, Vol. 28, No. 2, 2011, pp. $46-68$

79. Until 2002, when they obtained their non-rural hukou.

80. Besides, following the relocation of Xiaodao inhabitants, parents could place their children in one of three primary schools of the neighbourhood, whereas there was only one primary school on the island. On access to education for migrant children, see Chloé Froissart, "The Hazards of the Right to an Education," China Perspectives, No. 48, July-August 2003, pp. 21-36.

81. "Response to 'The problem of pensions and other such problems raised by Huang Jienan and other members of the mass,"' Letter from the Subdistrict Office, 31 May 2012.

82. Ibid.

83. Residents gave me two satirical posters created in 2012 that mock officials responsible for relocation, who were photographed by local dwellers with cell phones during altercations in front of the Guangzhou City Hall.

84. Urban dwellers hold a "non-rural hukou," not an "urban hukou." 